\title{
Quality characteristics of chevon obtained from goat fed melon (Colocynthis citrillus) h usk and palm (Elaeis guineensis) oil slurry
}

K.A Sanwo ${ }^{1}$, S.O Iposu ${ }^{1}$, J.A Adegbite ${ }^{1}$, S.S Abiola ${ }^{1}$, A.O. Fanimo ${ }^{1}$ and O.B. Oyewole ${ }^{2}$.

${ }^{1}$ Department of Animal Production and Health, ${ }^{2}$ Department of Food Science and Technology. Federal University of Agriculture, PMB 2240 Abeokuta, Nigeria.

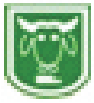

$$
\text { University of Agriculture, PMB } 2240 \text { Abeokuta, Nigenia. }
$$

\section{Abstract}

A study was undertaken to determine effect of nutritional value of melon (Colocynthis citrillus) husk (MH) and palm (Elaeis guineensis) oil slurry (POS) on quality of chevon obtained from West African Dwarf (WAD) goats finished on four diets viz. diet 1 ( $0 \% \mathrm{MH}, 0 \% \mathrm{POS})$; diet $2(50 \% \mathrm{MH}, 0 \% \mathrm{POS})$; diet $3(0 \% \mathrm{MH}, 50 \%$ POS) and diet 4 (50\% MH, 50\% POS). All animals were fed a basal diet of Panicum maximum ad libitum. After sixty days, eight goats (two goats per treatment) were slaughtered and muscles obtained from their forelegs. A sample of the raw meats was taken for $\mathrm{pH}$ measurement and Fatty acid analyses while the remaining was cooked by boiling and used for proximate analysis, cooking and refrigerated losses, and sensory evaluation. Data were subjected to one - way analysis of variance in a completely randomized design. Percent dry matter of the experimental diets ranged from $89.53 \%$ to $89.81 \%$. The cooking weight loss for chevon showed no significant $(P>0.05)$ difference but refrigerated weight loss (drip loss) showed significant $(P<0.05)$ difference due to diets; lowest values were recorded on diets $2(0.96 \mathrm{~g})$ and $4(0.91 \mathrm{~g})$, respectively. Chevon obtained from animals fed diet 3 had the lowest percent crude protein content (21.51\%) and highest cooking and refrigeration losses of $4.44 \%$ and $23.51 \%$, respectively. Chevon obtained from all the diets fed gave significant $(P<0.05)$ lower percentage values for linolenic acid compare with the control, while chevon from goats fed diet 3 gave a reduced percentage value of saturated fatty acids. In all the parameters considered for sensory evaluation, only flavour and saltiness showed significant $(P<0.05)$ difference. It was concluded that Melon husk and palm oil slurry can be added at the various inclusion rates in this study depending on consumer preferences for either nutrient qualities or sensory properties of meat.

Keywords: Chevon, West African dwarf goats, Melon husk, Palm Oil Slurry.

\section{Introduction}

The strength of a nation depends on the wealth of food it can provide for its people. However, it is sad to note that in most of the developing nations, the provision and availability of these foods in their right proportion for their citizens has continued to mount severe pressure on existing food resources. With the increasing demand for dietary protein in Nigeria due to population increase, more emphasis is being placed on small ruminants, for meat production. Feeding, which accounts for nearly $70 \%$ of production cost has necessitated the need to search for alternative feed resources which are cheaper and of no dietary importance to man (Fetuga and Tewe, 1985). In recent past, efforts have been geared towards the use of alternative feedstuff, which can help reduce the cost of production. To this end, a lot of successes have been made in feeding both monogastrics and ruminant animals (Hutagalung, 1981; Fanimo and FashinaBombata, 1997; Akinola and Abiola, 1999; Abiola and Adekunle, 2001). In spite of these successes, less cognizance is being giving to the effect of this feed resources on the quality of meat the animals produces, since studies have shown that feed quality is one of the factors that affects meat quality (Ikeme, 1990). 
Meat, particularly red meat, has been associated with unfavourable publicity about its negative effects on human health, especially its contribution to high levels of dietary fat and consequently saturated fatty acid intake (Langesen and Swinburn, 2006), which is believed to be a risk factor of heart disease. Meat with healthy fatty acid composition contains a lower amount of saturated fatty acids and that fat contains a high amount of the conjugated linoleic acid (CLA) (Scollan et al., 2001, Nuernberg et al., 2005). Since consumers are now conscious of the quality of meat being consumed, the aim of this study is to examine the nutritional value of this concentrate based diet on quality of meat obtained from West African Dwarf goats.

\section{Materials and Methods}

The feeding experiment was conducted at the small ruminant experimental unit of the Teaching and Research Farms, University of Agriculture, Abeokuta.

Sixteen intensively managed West African dwarf goats aged 19 - 20 months were quarantined for 32 days during which they were treated against ectoparasites by bathing them with Asuntol ${ }^{\circledR}$. They were also treated against endoparasites by subcutaneous injection of Kepromec at the rate of $0.2 \mathrm{ml} / 10 \mathrm{~kg}$ liveweight. Oxytetracycline (LA) antibiotic was also administered against infections such as respiratory, urinary tract infection, pneumonia etc. The goats were vaccinated against PPR (Peste des Petit Ruminant) with tissue cultured Rinderpest vaccine. After quarantine, the goats were transferred into individual experimental pens, which had been disinfected with Morigad ${ }^{\circledR}$ solution. The goats were randomly allotted into four dietary treatment groups of four replicate each (a goat per replicate) in a completely randomized design. All animals were fed a basal diet of Panicum maximum ad libitum. They were finished off with diets containing; diet 1 (control) $0 \% \mathrm{MH}$, $0 \%$ POS; diet 2 contained $50 \% \mathrm{MH}, 0 \%$ POS; diet 3 contained $0 \% \mathrm{MH}, 50 \%$ POS and diet 4 containing $50 \% \mathrm{MH}, 50 \%$ POS for two months as shown in Table 1. Two goats were slaughtered from each treatment, and meat from their fore limbs was used for the various analyses. A sample of the raw meats was taken for $\mathrm{pH}$ measurement and Fatty acid analyses while the remaining was cooked by boiling and used for proximate analysis, cooking and refrigerated losses, and sensory evaluation. All parameters were measured in triplicates of the chevon samples.

\section{Determination of cooking loss of Chevon}

Each sample was put in an air tight transparent polythene bag to prevent in and out flow of liquid from the polythene. Initial weight of treatment samples were recorded (using the Mettler toledo 4000 sensitive scale) before cooking in a water bath at temperature of $70^{\circ} \mathrm{C}$ for 15 minutes. Final weights of the samples were taken after allowing cooked samples to cool at room temperature for 20 minutes, for the determination of cooking weight loss (http://www.ochef.com/418.htm). Samples from each replicate were later cut into small sizes for sensory quality assessment.

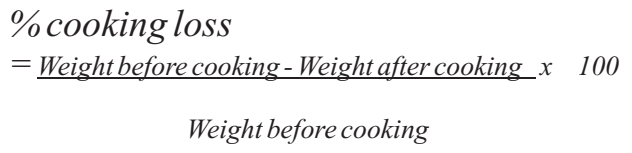

\section{Proximate analysis and $\mathrm{pH}$ of chevon}

Parameters evaluated include dry matter, crude protein, ether extract, and ash were determined using the methods of A.O.A.C. (1984). Fatty acid composition such as Palmitic, Stearic, Oleic, Linoleic and Lauric acids were also determined using the 
gas-liquid Chromatography as described in A.O.A.C. (1990). The pH of fresh chevon was determined after 7 hours using the Jenway $3015 \mathrm{pH}$ meter.

Determination of refrigeration loss (drip loss) of chevon

Treatment samples of cooked chevon were labelled and weighed before refrigeration and re-weighed after 24 hours of refrigeration at $2^{\circ} \mathrm{C}$. Refrigeration loss was the difference between the pre and postrefrigeration weights of the samples

Refrigeration loss $=$ weight of samples before refrigeration - weight of sample after refrigeration

Sensory evaluation

Sensory evaluation of samples of cooked chevon was assessed by ten (10) trained panellists. Meat quality parameters assessed were colour, juiciness, meaty flavour, tenderness, saltiness, overall flavour and overall acceptability.

Bite size portions of $10 \mathrm{~g}$ each were served at room temperature to panellists who were asked to comment freely on each sample served. For each parameter, the panellists awarded scores using a 9-point Hedonic scale $(1=$ Dislike extremely, $2=$ Dislike very much, 3=Dislike moderately, 4= Dislike slightly, 5= Intermediate, 6=Like slightly, $7=$ Like moderately, $8=$ Like very much,9=Like extremely)

\section{Statistical analysis}

All the data generated in this study were subjected to one - way analysis of variance in a completely randomized design using the statistical package (SPSS, 1999). Significant differences were separated using Duncan Multiple Range Test within the same package.

\section{Results}

The chemical compositions of experimental diets in this study are presented in Table 1. The proximate composition of meat showed that all parameters measured were significantly $(\mathrm{P}<0.05)$ affected by dietary treatments as shown in table 2. Dry matter of chevon ranged between $30.18 \%$ in Diet 1 to $31.76 \%$ in Diet 2. There was significant $(\mathrm{P}<0.05)$ difference in crude protein $(\mathrm{CP})$ content of the chevon samples. Chevon from goats fed diet 1 had the highest value of $23.19 \%$ while those fed diet 3 had the lowest CP content of $21.51 \%$. Crude fat of chevon obtained from animals fed diet 4 was significantly $(\mathrm{P}<0.05)$ the highest $(8.10 \%)$ compared to that $(7.85 \%)$ obtained from animals fed diet 1 (control). However, $\mathrm{pH}$ of chevon was higher for animals fed Diet $1(5.70 \%)$ and Diet 2 (5.68) that were statistically at par while chevon of animals fed diet 3 (5.50) and 4 (5.53) were lower and also

Table 1: Chemical composition of experimental diets (\%DM)

\begin{tabular}{llllc}
\hline \multicolumn{5}{l}{$\mathbf{5 0 \%}$ inclusion levels } \\
\hline Parameters & $\mathbf{1}$ & $\mathbf{2}$ & $\mathbf{3}$ & $\mathbf{4}$ \\
\hline Dry matter & 89.78 & 89.81 & 89.53 & 89.69 \\
Crude protein & 14.65 & 12.84 & 12.52 & 11.94 \\
Crude fibre & 18.68 & 33.73 & 29.58 & 32.13 \\
Ether extract & 3.75 & 9.17 & 12.85 & 15.73 \\
Metabolizable Energy $(\mathrm{MJ} / \mathrm{kg})$ & 12.30 & 11.04 & 11.10 & 10.98 \\
\hline
\end{tabular}

Diet $1=0 \% \mathrm{MH} ; 0 \%$ POS; $\quad$ Diet $2=50 \% \mathrm{MH} ; 0 \% \mathrm{POS} ; \quad$ Diet $3=0 \% \mathrm{MH} ; 50 \%$ POS;

Diet $4=50 \% \mathrm{MH} ; 50 \%$ POS; $\mathrm{MH}=$ Melon husk, POS = Palm oil slurry 
Quality characteristics of chevon obtain ed from goat fed melon husk and palm oil slur ry

Table 2: Proximate analysis, pH and Fatty acid composition (\%) of chevon obtained from West African dwarf goats fed the experimental diets

\begin{tabular}{|c|c|c|c|c|c|}
\hline \multirow[b]{2}{*}{ Parameters (\%) } & \multicolumn{4}{|c|}{$50 \%$ inclusion levels } & \multirow[b]{2}{*}{ SEM } \\
\hline & 1 & 2 & 3 & 4 & \\
\hline Dry matter & $30.18^{b}$ & $31.76^{\mathrm{a}}$ & $31.0^{\mathrm{ab}}$ & $30.74^{\mathrm{b}}$ & 0.21 \\
\hline Crude protein & $23.19^{\mathrm{a}}$ & $22.91^{\mathrm{b}}$ & $21.51^{\mathrm{c}}$ & $22.79^{\mathrm{b}}$ & 0.19 \\
\hline Fat & $7.85^{\mathrm{b}}$ & $8.02^{\mathrm{a}}$ & $7.96^{\mathrm{b}}$ & $8.10^{\mathrm{a}}$ & 0.27 \\
\hline $\mathrm{pH}$ & $5.70^{\mathrm{a}}$ & $5.68^{\mathrm{a}}$ & $5.50^{\mathrm{b}}$ & $5.53^{\mathrm{b}}$ & 0.28 \\
\hline \multicolumn{6}{|c|}{ Satu rated Fatty acids } \\
\hline Palmitic acid & $28.60^{\mathrm{a}}$ & $25.89^{\mathrm{b}}$ & $16.90^{\mathrm{d}}$ & $20.43^{\mathrm{c}}$ & 1.38 \\
\hline Stearic acid & $20.32^{\mathrm{a}}$ & $18.18^{\mathrm{b}}$ & $12.53^{\mathrm{d}}$ & $15.43^{\mathrm{c}}$ & 0.89 \\
\hline \multicolumn{6}{|c|}{$\begin{array}{l}\text { Unsaturated Fatty } \\
\text { acids }\end{array}$} \\
\hline Oleic acid & $34.29^{\mathrm{b}}$ & $36.01^{\mathrm{a}}$ & $26.70^{\mathrm{c}}$ & $22.53^{\mathrm{d}}$ & 1.68 \\
\hline Linoleic acid & $14.18^{\mathrm{a}}$ & $14.18^{\mathrm{a}}$ & $8.51^{\mathrm{b}}$ & $6.51^{\mathrm{c}}$ & 0.93 \\
\hline Lauric acid & 3.37 & 3.37 & 2.49 & 2.23 & 0.18 \\
\hline
\end{tabular}

${ }^{a}, b, c:$ Means along the same row with different superscripts are significant $(\mathrm{p}<0.05)$

SEM: Standard Error of Means

Diet $1=0 \% \mathrm{MH} ; 0 \%$ POS; Diet $2=50 \% \mathrm{MH} ; 0 \%$ POS; Diet $3=0 \% \mathrm{MH} ; 50 \% \mathrm{POS}$;

Diet $4=50 \% \mathrm{MH} ; 50 \%$ POS; $\mathrm{MH}=$ Melon husk, POS = Palm oil slurry.

statistically similar. Chevon obtained from animals fed diet 3 had the lowest palmitic and stearic acid contents of $16.90 \%$ and $12.53 \%$, respectively. Chevon obtained on diet 1 (control) had the highest values of $28.60 \%$ and $20.32 \%$ for palmitic and stearic acids, respectively. Chevon obtained on

Table 3: Cooking and refrigeration weight losses in chevon produced from West African dwarf goats fed the experimental diets.

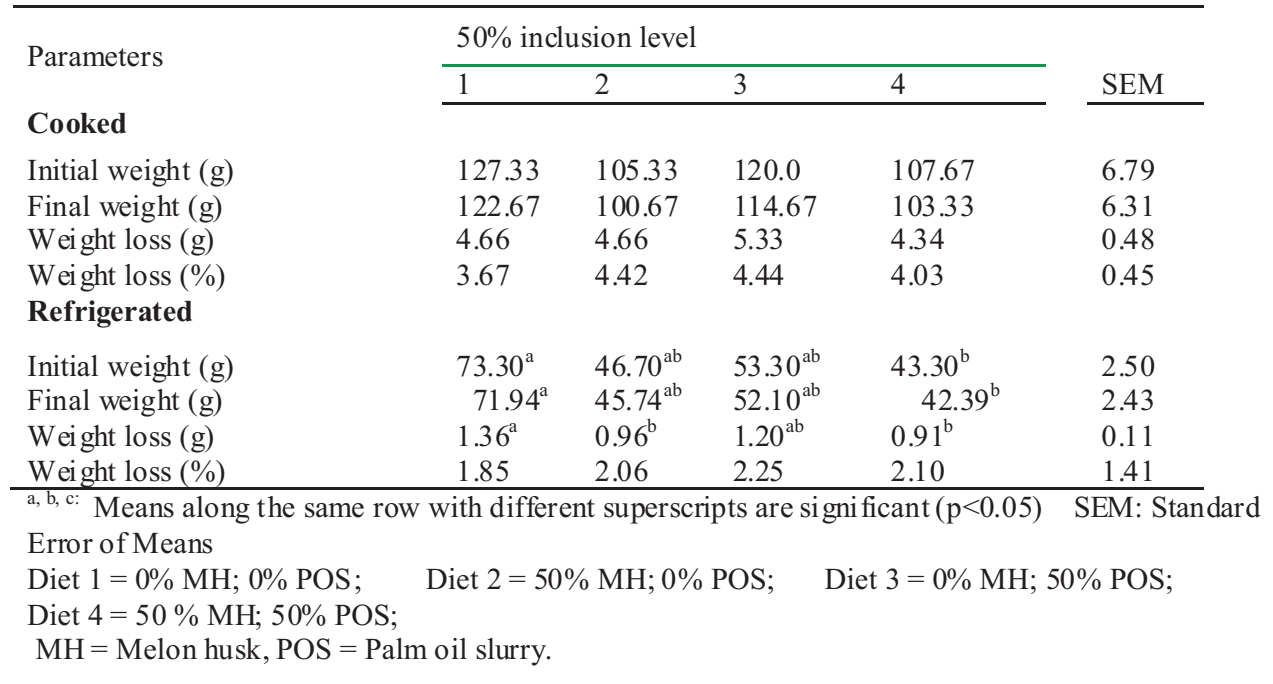


Table 4: Sensory properties of chevon produced from West African dwarf goats fed the experimental diets.

\begin{tabular}{|c|c|c|c|c|c|}
\hline \multirow[b]{2}{*}{ Parameter } & \multicolumn{4}{|c|}{$50 \%$ inclusion level } & \multirow[b]{2}{*}{ SEM } \\
\hline & 1 & 2 & 3 & 4 & \\
\hline Colour & 6.0 & 6.0 & 6.0 & 6.0 & 0.16 \\
\hline Juiciness & 6.0 & 5.0 & 6.0 & 5.0 & 0.12 \\
\hline Meaty Flavour & $6.6^{\mathrm{a}}$ & $5.9^{\mathrm{c}}$ & $6.2^{\mathrm{b}}$ & $6.6^{\mathrm{a}}$ & 0.11 \\
\hline Tenderness & 6.0 & 6.0 & 6.0 & 5.0 & 0.14 \\
\hline Saltiness & $4.1^{\mathrm{d}}$ & $4.2^{\mathrm{c}}$ & $5.5^{\mathrm{a}}$ & $5.1^{\mathrm{b}}$ & 0.20 \\
\hline Overall flavour & 6.0 & 6.0 & 6.0 & 6.0 & 0.13 \\
\hline Overall acceptability & 7.0 & 6.0 & 7.0 & 6.0 & 0.15 \\
\hline
\end{tabular}

diet 2 had the highest concentration of oleic, linoleic and lauric acids of $36.01 \%, 14.18 \%$ and $3.37 \%$, respectively, while chevon for diet 4 had the lower values of $22.53 \%$, $6.51 \%$ and $2.23 \%$ respectively.

Table 3 shows the cooked and refrigerated weight losses of chevon. Differences in cooking losses were not significant while significant $(\mathrm{P}<0.05)$ differences were observed for refrigerated losses. Chevon obtained in animals on diet 3 had the highest percentage cooking and refrigeration losses of $4.44 \%$ and $2.25 \%$ while those on diet 1 had the lowest value of $3.67 \%$ and $1.85 \%$, respectively.

Table 4 shows the results of sensory evaluation panel for the boiled chevon samples. Meaty flavour and saltiness were significantly $(\mathrm{P}<0.05)$ different. Chevon from Diets 1 and 4 were the most preferred at 6.6 points (like moderately) regarding Meaty flavour while Diet 2 was the least preferred at 5.9 points (like slightly). Saltiness was best in Diet 3 at 5.5 points (intermediate) and least in Diet 1 at 4.1 points (dislike slightly).

\section{Discussion}

The values obtained for the proximate analysis of Chevon (goat meat) differ among the dietary treatments. These findings are contrary to those of Realini et al. (2007) who observed no significant differences in the dietary fatty acids profile of pork fat content and distribution in pigs fed a by-product of the olive industry (Greedy-Grass OLIVA®: 1.4\% growing, $3.8 \%$ finishing) known to be an elevated monounsaturated fat diet.

The difference in $\mathrm{pH}$ values obtained from the dietary treatments varied slightly from each other $(5.53-5.70)$ which had made them to be slightly acidic. This can be attributed to the effect of glycolysis which occurred after death and thereby making the ultimate $\mathrm{pH}$ which usually range between 7 -7.20 to fall to a range of $5.30-5.50$ in a normal meat (Ikeme, 1990). The values for the saturated fatty acids obtained in Palmitic and Stearic acid were highest in products obtained from Diets 1 and 2, and not Diets 3 and 4 which are sources of oil. Since meat and milk of ruminant origin contain a substantial proportion of saturated lipids resulting from lipolysis and biohydrogenation of dietary unsaturated lipids by rumen microorganisms (Mac et 
al., 2005), diets 3 and 4 which are oil sources might have prevented lipolysis and hydrogenation of the dietary lipids by rumen microorganisms which has resulted in lower values obtained. Furthermore, if a more unsaturated lipid composition is desired, rumen hydrogenation must be prevented, and this can be achieved by chemical modification of dietary lipids or feeding a dietary lipid where the oil seed itself provides some degree of protection from rumen microbial activity (Dunne et $a l ., 2007)$. Oleic acid is a fatty acid found in animal and vegetable oils which occurs naturally in greater quantities than any other fatty acid and it is known to lower blood levels of Cholesterol. Food products from ruminants are the major dietary source of Conjugated Linoleic Acid (CLA) for humans (Bauman et al., 1999).

Chevon from goats on diet 3 had the highest cooking and refrigeration losses of $4.44 \%$ and $23.51 \%$, respectively, while chevon from goats on diet 1 had the lowest cooking and refrigerated losses of $3.67 \%$ and $18.55 \%$, respectively. Water holding capacity (WHC) has been defined as the ability of meat to retain water during application of external forces such as cutting, heating, grinding or refrigeration (Forest, et al., 1975), therefore, low WHC of boiled chevon from animals on diet 3 may be attributed to its $\mathrm{pH}$ level of 5.50 since $\mathrm{WHC}$ is at its minimum at lower $\mathrm{pH}$ (Ikeme, 1990).

Sensory evaluation of cooked chevon obtained from animals fed dietary treatments indicated that colour, juiciness, tenderness, overall flavour and acceptability were not influenced by the dietary treatment except meaty flavour and saltiness, which were more preferred in chevon obtained from goats on diets 1 . These may be attributed to its very low refrigerated weight loss thus, indicating a higher water holding capacity, since many of the physical properties of meat including colour, texture, flavour e.t.c. are partially dependent on water holding capacity as reported by Lawrie (1985)

\section{Conclusion}

This study has shown that chevon obtained from WAD goats fed diets containing $\mathrm{MH}$ and POS at $50 \%$ level of supplementation had a desirable \%CP in all diets. However, only chevon obtained from goats fed diets 3 and 4 gave a better and healthy saturated fatty acid composition of Palmitic and Stearic acids, while the control diet gave a better meaty flavour of chevon as influenced by its better water holding capacity. It was concluded that Melon husk and palm oil slurry can be added at the various inclusion rates in this study depending on consumer preferences for either nutrient qualities or sensory properties of meat.

\section{References}

AOAC, 1990. Official methods of Analysis, 15th ed. Association of Analytical Chemists, Washington, DC.

Abiola, S.S and Adekunle, O.A 2001: Nutritive value of melon husk in the diet of Chickens. Bioresource Technology. 811, 265-267.

Akinola, S.O., Abiola, S.S. 1999. Blood Chemistry and Carcass yield of Cockerels Fed melon husk diets. Trop. J. Animal Sci. 2(2039-44.

Bauman, D. E., Baumgard, L. H. Cor, B. A. And J. M. Griinari. 1999. In Biosynthesis of conjugated linoleic acid in ruminants. Proceedings of the American Society of Animal Science. Pp 1- 15.

Dunne, P.G., Rogalski, J., Childs,S., Monahan,F. J., Kenny, D.A and 
M o l o n e y, A. P. 2007 . Supplementation of heifers with ruminally-protected polyunsaturated fatty acid: Effects on colour stability of retail packaged minced beef.

Fanimo A.O. and Fashina - Bombata, H.A. 1997. The response of weaner pigs to diets containing palm oil slurry. Animal Feed Science Technology 71. Pp. $191-195$.

Fetuga, B.L. and Tewe, O.O. 1985. Potentials of Agro Industrial byproducts and crop residues as animal feeds. Nig. Food J. 2(2):136 - 141.

Forest, J.C., Aberie, E.D., Edric, H.B, Judge, M.E. and Merkel, R.A. 1975. 'Deterioration of meat'. In Principles of Meat Science W.H. Freeman and Coy, San Francisco, Pp. 240 - 250.

http://www.sensorysociety.org/ssp/wiki/Ve rbal_Hedonic_Scale/

Hutagalung, R.L. 1981. Utilization of Cocoa by-products as animal feed. Proc. Conf. on Cocoa and Coconuts, Kualar Iwupur, Incorporated Society of Planters. Pp 447-456

Ikeme, A. I. 1990. Meat Science and Technology. A comprehensive approach. Africana - Fep Publishers Limited. Pp 144.

Langesen, M. and Swimburn, B 2006. The New Zealand food supply and diet-trends. New Zealand Medical Journal. 113:311-315.

Lawrie, R.A., 1985. Meat Science. Fourth Edition, Pergamon Press, Oxford
MacRae, J., O'Reilly, L and Morgan, P. 2005. Desirable characteristics of animal products from a human health perspective. Livestock Production Science, 94: 95-103.

Nuernberg, K., Dannenberger, D., Nuernberg, G., Ender, K., Scollan, N., Wood, J., Nut G and Richardson, I. 2005. Effect of a grass- based and a concentrate feeding system on meat quality characteristics and fatty acid composition of longissimus muscle in different cattle breeds. Livestock Production Science, 94, 137- 147.

Realini, C.E., Duran,P., Lizardo, R.,Gispert, M., Oliver, M.A and Estreve-Garcia E. 2007. Effect of dietary fatty acid profile on pork carcass fat content and distribution In; Harnessing and exploiting global opportunities. Proceedings of the $52^{\text {nd }}$ International Congress of Meat Science and Technology held on $13^{\text {th }}-$ $18^{\text {th }}$ Aug 2006, Dublin, Ireland. D. Troy, R. Pearce, B. Byrne, and J. Kerry (eds.). Wageningen Academic Publishers. pp 163-164.

Scollan, N. D., Dhanoa, M.S., Choi, N.J., Maeng, W.J., Enser, $M$ and Wood, J.D. 2001. Biohydrogenisation and digestion of long chain fatty acids in steers fed on different sources of lipid. J.Agric.Sci, 136- 355.

SPSS. 1999. Statistical Package for Social Sciences. Procedure and Facilities for release. McGraw-Hill Book Co. N.Y.

Received: 10th December, 2010 Accepted: 4th March, 2011 